University of Nebraska - Lincoln

DigitalCommons@University of Nebraska - Lincoln

Publications from USDA-ARS / UNL Faculty

U.S. Department of Agriculture: Agricultural

Research Service, Lincoln, Nebraska

2011

Evaluating decision rules for dryland rotation crop selection

David C. Nielsen

USDA-ARS, dcnielsen55@gmail.com

Merle F. Vigil

USDA-ARS

Joseph G. Benjamin

USDA-ARS

Follow this and additional works at: https://digitalcommons.unl.edu/usdaarsfacpub

Part of the Agricultural Science Commons

Nielsen, David C.; Vigil, Merle F.; and Benjamin, Joseph G., "Evaluating decision rules for dryland rotation crop selection" (2011). Publications from USDA-ARS / UNL Faculty. 867.

https://digitalcommons.unl.edu/usdaarsfacpub/867

This Article is brought to you for free and open access by the U.S. Department of Agriculture: Agricultural Research Service, Lincoln, Nebraska at DigitalCommons@University of Nebraska - Lincoln. It has been accepted for inclusion in Publications from USDA-ARS / UNL Faculty by an authorized administrator of DigitalCommons@University of Nebraska - Lincoln. 


\title{
Evaluating decision rules for dryland rotation crop selection
}

\author{
David C. Nielsen*, Merle F. Vigil, Joseph G. Benjamin \\ USDA-ARS, Central Great Plains Res. Stn., 40335 County Road GG, Akron, CO 80720, United States
}

\section{A R T I C L E I N F O}

\section{Article history:}

Received 25 August 2010

Received in revised form 20 October 2010

Accepted 22 October 2010

\section{Keywords:}

Dryland cropping systems

Opportunity cropping

Water use

Yield

Water use efficiency

Precipitation use efficiency

Economic returns

\begin{abstract}
A B S T R A C T
No-till dryland winter wheat (Triticum aestivum L.)-fallow systems in the central Great Plains have more water available for crop production than the traditional conventionally tilled winter wheat-fallow systems because of greater precipitation storage efficiency. That additional water is used most efficiently when a crop is present to transpire the water, and crop yields respond positively to increases in available soil water. The objective of this study was to evaluate yield, water use efficiency (WUE), precipitation use efficiency (PUE), and net returns of cropping systems where crop choice was based on established crop responses to water use while incorporating a grass/broadleaf rotation. Available soil water at planting was measured at several decision points each year and combined with three levels of expected growing season precipitation $(70,100,130 \%$ of average $)$ to provide input data for water use/yield production functions for seven grain crops and three forage crops. The predicted yields from those production functions were compared against established yield thresholds for each crop, and crops were retained for further consideration if the threshold yield was exceeded. Crop choice was then narrowed by following a rule which rotated summer crops (crops planted in the spring with most of their growth occurring during summer months) with winter crops (crops planted in the fall with most of their growth occurring during the next spring) and also rotating grasses with broadleaf crops. Yields, WUE, PUE, value-basis precipitation use efficiency (\$PUE), gross receipts, and net returns from the four opportunity cropping (OC) selection schemes were compared with the same quantities from four set rotations [wheat-fallow (conventional till), (WF (CT)); wheat-fallow (no-till), (WF (NT)); wheat-corn (Zea mays L.)-fallow (no-till), (WCF); wheat-millet (Panicum miliaceum L.) (no-till), (WM)]. Water use efficiency was greater for three of the OC selection schemes than for any of the four set rotations. Precipitation was used more efficiently using two of the OC selection schemes than using any of the four set rotations. Of the four OC cropping decision methods, net returns were greatest for the method that assumed average growing season precipitation and allowed selection from all possible crop choices. The net returns from this system were not different from net returns from WF (CT) and WF (NT). Cropping frequency can be effectively increased in dryland cropping systems by use of crop selection rules based on water use/yield production functions, measured available soil water, and expected precipitation.
\end{abstract}

Published by Elsevier B.V.

\section{Introduction}

Dryland cropping systems in the Great Plains are subject to wide variations in productivity and profitability (Dhuyvetter et al., 1996) due to the highly variable nature of the limited precipitation across the region (Nielsen et al., 2010). The traditional wheat-fallow production system of the region was developed in the 1930 s as a strategy to minimize incidence of crop failures resulting from

Abbreviations: OC, opportunity cropping; PUE, precipitation use efficiency; \$PUE, value-basis precipitation use efficiency; WUE, water use efficiency; WF (CT), wheat-fallow (conventional till); WF (NT), wheat-fallow (no till); WCF (NT), wheat-corn-fallow (no till); WM (NT), wheat-millet (no till).

* Corresponding author. Tel.: +1 970345 0507; fax: +1 9703452088.

E-mail address: david.nielsen@ars.usda.gov (D.C. Nielsen). erratic precipitation (Hinze and Smika, 1983). The use of herbicides for weed control in this system reduced or eliminated tillage, and led to greater precipitation storage efficiencies (Farahani et al., 1998; Nielsen et al., 2005; Nielsen and Vigil, 2009), such that more frequent cropping could occur (Halvorson and Reule, 1994; Peterson et al., 1993; Anderson et al., 1999; Norwood et al., 1990; Smika, 1990). In particular, both Farahani et al. (1998) and Nielsen and Vigil (2009) pointed out the extremely inefficient precipitation storage that occurred during the second summer fallow period (May through September) during the last 5 months of the 14-month fallow period of the wheat-fallow system. In many instances precipitation storage efficiency during these hot and windy months which can have many days and sometimes weeks between precipitation events was negative, indicating evaporative loss of all of the precipitation occurring during those 5 months plus evaporative loss of some soil water stored earlier in the fallow period. 
Table 1

Planting, harvesting, and fertilizing details for opportunity cropping system and fixed rotation crops, Akron, CO, $2001-2005$.

\begin{tabular}{|c|c|c|c|c|c|c|c|}
\hline \multirow[t]{2}{*}{ Year } & \multirow[t]{2}{*}{ Crop } & \multirow[t]{2}{*}{ Variety } & \multirow[t]{2}{*}{ Planting date } & \multirow[t]{2}{*}{ Harvest date } & \multirow[t]{2}{*}{ Seeding rate } & \multicolumn{2}{|l|}{ Fertilizer } \\
\hline & & & & & & $\mathrm{kg} \mathrm{Nha}^{-1}$ & $\mathrm{kgP}_{2} \mathrm{O}_{5} \mathrm{ha}^{-1}$ \\
\hline \multirow[t]{6}{*}{2001} & Wheat & Akron & 26 September 2000 & 9 July & $67 \mathrm{~kg} \mathrm{ha}^{-1}$ & 67 & 22 \\
\hline & Corn & NK4242BT & 16 May 2001 & 23 October & $41,020 \mathrm{sha}^{-1}$ & 90 & 22 \\
\hline & Proso Millet & Huntsman & 25 June 2001 & 12 September & $17 \mathrm{~kg} \mathrm{ha}^{-1}$ & 45 & 17 \\
\hline & Foxtail Millet & Golden German & 25 June 2001 & 29 August & $11 \mathrm{~kg} \mathrm{ha}^{-1}$ & 67 & 17 \\
\hline & Pea & Profi & 10 April 2001 & 10 July & $202 \mathrm{~kg} \mathrm{ha}^{-1}$ & Inoculated & 22 \\
\hline & Canola & Hyola & 6 April 2001 & 3 July & $10 \mathrm{~kg} \mathrm{ha}^{-1}$ & 0 & 0 \\
\hline \multirow[t]{5}{*}{2002} & Wheat & Akron & 20 September 2001 & 1 July & $67 \mathrm{~kg} \mathrm{ha}^{-1}$ & 67 & 22 \\
\hline & Corn & NK4242BT & 5 May 2002 & No harvest & $41,000 \mathrm{~s} \mathrm{ha}^{-1}$ & 67 & 22 \\
\hline & Proso Millet & Sunup & 12 June 2002 & No harvest & $17 \mathrm{~kg} \mathrm{ha}^{-1}$ & 90 & 22 \\
\hline & Foxtail Millet & Golden German & 18 June 2002 & No harvest & $13 \mathrm{~kg} \mathrm{ha}^{-1}$ & 45 & 22 \\
\hline & Sunflower & Triumph 665 & 3 June 2002 & No harvest & $41,000 \mathrm{~s} \mathrm{ha}^{-1}$ & 0 & 21 \\
\hline \multirow[t]{4}{*}{2003} & Wheat & Akron & 25 September 2002 & 15 July & $67 \mathrm{~kg} \mathrm{ha}^{-1}$ & 67 & 22 \\
\hline & Corn & NK4242BT & 21 May 2003 & 7 October & $34,590 \mathrm{~s} \mathrm{ha}^{-1}$ & 67 & 22 \\
\hline & Proso Millet & Sunup & 20 June 2003 & 21 August & $17 \mathrm{~kg} \mathrm{ha}^{-1}$ & 56 & 22 \\
\hline & Sunflower & Triumph 665 & 10 June 2003 & 21 October & 40,350 s ha $^{-1}$ & 0 & 22 \\
\hline \multirow[t]{4}{*}{2004} & Wheat & Akron & 19 September 2003 & 13 July & $67 \mathrm{~kg} \mathrm{sha}^{-1}$ & 56 & 22 \\
\hline & Corn & N42B7 & 3 June 2004 & 26 October & $29,640 \mathrm{~s} \mathrm{ha}^{-1}$ & 67 & 22 \\
\hline & Proso Millet & Sunup & 7 June 2004 & 17 September & $17 \mathrm{~kg} \mathrm{ha}^{-1}$ & 50 & 17 \\
\hline & Forage Pea & Arvika & 28 April 2004 & 26 July & $157 \mathrm{~kg} \mathrm{ha}^{-1}$ & Inoculated & 22 \\
\hline \multirow[t]{5}{*}{2005} & Wheat & Akron & 27 September 2004 & 7 July & $67 \mathrm{~kg} \mathrm{ha}^{-1}$ & 56 & 34 \\
\hline & Corn & N42B7 & 18 May 2005 & 3 November & 29,640 s ha $^{-1}$ & 67 & 0 \\
\hline & Proso millet & Sunup & 10 June 2005 & 2 September & $17 \mathrm{~kg} \mathrm{ha}^{-1}$ & 56 & 22 \\
\hline & Foxtail millet & Golden German & 10 June 2005 & 8 September & $13 \mathrm{~kg} \mathrm{ha}^{-1}$ & 56 & 22 \\
\hline & Pea & Profi & 8 April 2005 & 14 July & $213 \mathrm{~kg} \mathrm{ha}^{-1}$ & Inoculated & 22 \\
\hline
\end{tabular}

Farahani et al. (1998) and Peterson and Westfall (2004) suggested that intensifying Great Plains dryland cropping systems by reducing or eliminating the occurrence of fallow as much as possible was the key to improving water use efficiency (WUE). Peterson and Westfall (2004) reported a 37\% increase in grain WUE when the cropping system was intensified from one crop in 2 years to three crops in 4 years. Silburn et al. (2007) noted that continuing to fallow after filling the soil profile to $80 \%$ available water capacity was highly inefficient because of losses to evaporation, runoff, and drainage below the root zone. They suggested that those water losses could be reduced using stored soil water and growing season precipitation more efficiently through OC rather than using a fixed rotation with set periods of fallow.

With OC (sometimes called flexible cropping) cropping frequency is increased by basing the decision on whether or not to fallow on the amount of soil water at planting time. Young and van Kooten (1989) noted that OC attempts to minimize the risks associated with continuous cropping in dryland regions. They stated that by opting to fallow in the driest springs, $\mathrm{OC}$ is able to remove some of the downside risk associated with a fixed rotation. Weisensel et al. (1991) used Monte Carlo simulation to demonstrate that OC based on available soil moisture at planting time resulted in more profitable cropping systems than traditional fixed rotations in Saskatchewan.

Unger (2001) evaluated dryland OC in the Texas panhandle with a variety of alternative crops for grain and forage. His strategy was to intensify cropping from the traditional wheat-sorghum [Sorghum bicolor (L). Moench]-fallow system to cropping as often as possible based on the available soil water (at least $0.60 \mathrm{~m}$ of wetted soil; wetted soil was not defined more specifically). He also stated that potential growing season precipitation should be favorable ("favorable" was likewise not defined), and alternative crop potential yield was not estimated in order to make a crop choice. He concluded that $O C$ provided for more intensive cropping than that achieved with fixed cropping systems, thereby making more efficient use of precipitation than achieved by cropping systems that included long fallow periods. Nielsen et al. (2005) showed that the \$PUE of the three opportunity cropping systems of Unger (2001) based on the average price received for the product was relatively high, ranging from $\$ 0.45 \mathrm{ha}^{-1} \mathrm{~mm}^{-1}$ to $\$ 1.21 \mathrm{ha}^{-1} \mathrm{~mm}^{-1}$. All three of those systems included a high percentage of forage crops.

Researchers in Montana and North Dakota promoted OC in the 1970 s to use precipitation more effectively to increase yields and to help prevent and control saline seeps (Brown et al., 1981). They recommended an available soil water content of at least $76 \mathrm{~mm}$ at planting to produce spring barley (Hordeum vulgare L.) or spring wheat. Other researchers reported winter wheat, proso millet, pinto bean (Phaseolus vulgaris L.), and grain sorghum grain yields to be highly correlated with amount of stored soil water at planting (Unger, 1978; Musick et al., 1994; Lyon et al., 1995, 2007; Nielsen et al., 1999, 2002; Stone and Schlegel, 2006). Similarly, dry matter yields of spring triticale (xTriticlsecale Wittmack) and foxtail millet (Setaria italica L. Beauv.) are well correlated with available soil water at planting (Felter et al., 2006).

In order to provide farmers with yield estimates for OC, Brown and Carlson (1990) published regression equations relating yield of winter wheat, spring wheat, barley, oat (Avena sativa L.), and safflower (Carthamus tinctorius L.) to the sum of plant available stored soil water at planting and growing season precipitation. Similar linear production functions (yield vs. water use) for corn, winter wheat, proso millet, pea (Pisum sativum L.), canola, (Brassica napus L.) sunflower (Helianthus annuus L.), soybean (Glycine max L.), winter triticale, and foxtail millet have been published for the central Great Plains (Nielsen, 1990, 1995, 1998, 1999, 2001, 2006a,b; Nielsen et al., 2006) and could be used to predict yields and guide crop selection in an OC system.

Another factor to consider in $\mathrm{OC}$ is the rotation effect (Pierce and Rice, 1988; Porter et al., 1997). Anderson (1998) suggested that in order to minimize negative weed, insect, and pathogen effects on yield, cropping systems should rotate broadleaf crops with grasses, and also rotate summer crops (crops planted in the spring with most of their growth occurring during summer months) with winter crops (crops planted in the fall with most of their growth occurring during the next spring) or spring crops (crops planted in the spring with most of their growth occurring during the spring). The objective of this experiment was to evaluate yield, WUE, PUE, and net returns of four OC systems where crop choice was based on several crop selection rules using crop responses to 
Table 2

Water use/yield production functions ( $\left.\mathrm{kg} \mathrm{ha}^{-1}=a \times[\mathrm{mm}-b]\right)$ and yield reporting moisture content for dryland crops in the central Great Plains.

\begin{tabular}{|c|c|c|c|c|}
\hline Crop & $\begin{array}{l}\text { Production } \\
\text { function slope } a \\
\left(\mathrm{~kg} \mathrm{ha}^{-1} \mathrm{~mm}^{-1}\right)\end{array}$ & $\begin{array}{l}\text { Production function } \\
\text { intercept } b(\mathrm{~mm})\end{array}$ & Source for production function & $\begin{array}{l}\text { Grain or dry matter yield } \\
\text { reporting moisture content } \\
\left(\mathrm{kg} \mathrm{kg}^{-1}\right)\end{array}$ \\
\hline Corn & 25.67 & 232 & Nielsen (1995) & 0.155 \\
\hline Winter wheat & 12.49 & 132 & Nielsen (2006b) & 0.125 \\
\hline Proso millet & 10.44 & 88 & Nielsen (2006b) & 0.120 \\
\hline Pea & 8.00 & 22 & Nielsen (2001) & 0.125 \\
\hline Canola & 7.73 & 158 & Nielsen (1998) & 0.080 \\
\hline Sunflower & 6.64 & 175 & Nielsen (1999) & 0.100 \\
\hline Soybean & 6.53 & 17 & Nielsen (1990) & 0.130 \\
\hline Forage triticale & 33.00 & 86 & Nielsen et al. (2006) & 0.000 \\
\hline Foxtail millet & 29.30 & 78 & Nielsen et al. (2006) & 0.000 \\
\hline Forage pea & 24.77 & 32 & Nielsen (2006a) & 0.000 \\
\hline
\end{tabular}

anticipated water use while incorporating a grass/broadleaf, summer crop/winter crop rotation scheme.

\section{Materials and methods}

This study was conducted at the USDA Central Great Plains Research Station, $6.4 \mathrm{~km}$ east of Akron, $\mathrm{CO}\left(40^{\circ} 09^{\prime} \mathrm{N}, 103^{\circ} 09^{\prime} \mathrm{W}\right.$, $1384 \mathrm{~m}$ ). The soil type was a Weld silt loam (fine, smectitic, mesic Aridic Argiustoll). Average annual precipitation at this location is $417 \mathrm{~mm}$. In 1990, several rotations were established to investigate the possibility of cropping more frequently than every other year, as done with the traditional winter wheat-fallow system. A description of the plot area, tillage systems, and experimental design are given in Bowman and Halvorson (1997) and Anderson et al. (1999). Briefly, rotation treatments were established in a randomized complete block design with three replications. All phases of each rotation were present every year. Individual plot size was $9.1 \mathrm{~m}$ by $30.5 \mathrm{~m}$, with east-west row direction. The current study analyzes data from the 2001 through 2005 time period. Crop varieties and planting, harvesting, and fertilizing dates and rates are given in Table 1. Nitrogen fertilizer rates varied slightly from year to year as those rates were based on typical application rates for dryland production in this region, adjusted occasionally for expected residual $\mathrm{N}$ amounts. Seed yield sample size was generally between 35 and $42 \mathrm{~m}^{2}$, and biomass (seed and forage) sample size was between 2.9 and $3.8 \mathrm{~m}^{2}$. Grain and dry matter yields are reported with the moisture contents shown in Table 2.

Four OC systems were evaluated, with the decision to plant a crop based on predicted yield exceeding an established threshold (Table 3) which was established in consultation with local producers. The predicted yield was calculated using a spreadsheet yield calculator (available at http://www.ars.usda.gov/Services/ docs.htm?docid=19206, verified 4/1/2010) which employed water use/yield production functions (Table 2) established at Akron, CO.
Water use was assumed to be the sum of measured available soil water just prior to planting and expected growing season precipitation, where expected growing season precipitation ranged from $70 \%$ of average to $130 \%$ of average (Table 3 ). The OC 1 system was considered to be a conservative system, where only $70 \%$ of average growing season precipitation was expected, and only the traditional dryland crops of winter wheat, corn, proso millet, and foxtail millet for forage were allowed as crop choices. The other three OC systems allowed for all possible crop choices that we had established production functions for, but expected growing season precipitation was $100 \%$ (OC2), $70 \%$ (OC3), or 130\% (OC4) of average.

Soil water was measured to a depth of $1.65 \mathrm{~m}$ in $0.30-\mathrm{m}$ intervals using a neutron probe for all depths except the 0.0-0.3-m layer. Soil water in this surface layer was determined using time-domain reflectometry with $0.3 \mathrm{~m}$ waveguides installed vertically to average the water content over the entire layer. The neutron probe was calibrated against gravimetric soil water samples taken in the plot area. Gravimetric soil water was converted to volumetric water by multiplying by the soil bulk density for each depth. Two measurement sites were located near the center of each plot and data from the two sites were averaged to give one reading of soil water content for each plot. Available water per plot was calculated as

(Volumetric water-lower limit) $\times$ layer thickness

where volumetric water $=\mathrm{m}^{3}$ water $\mathrm{m}^{-3}$ soil from neutron probe or time-domain reflectometry measurements, lower limit= lowest volumetric water observed under these crops in the plot area (Ritchie, 1981; Ratliff et al., 1983), and layer thickness $=0.3 \mathrm{~m}$. The lower limits used to calculate available water are given in Table 4. Available water for each plot was calculated as the sum of available water from all six measurement depths. The soil water measurements were made at several decision points during the year (mid-September for winter wheat and forage triticale decision; end of March for canola, pea, and forage pea decision; end

Table 3

Crop choice decision rules, available crop choices, and yield thresholds.

\begin{tabular}{|c|c|c|}
\hline Opportunity cropping system & $\begin{array}{l}\text { Estimated water use used to calculate crop } \\
\text { choice yield }\end{array}$ & Available crop choices ${ }^{\mathrm{a}}$ \\
\hline OC1 & $\begin{array}{l}\text { Measured available soil water }+70 \% \text { of average } \\
\text { growing season precipitation }\end{array}$ & Wheat, corn, proso millet, foxtail millet \\
\hline OC2 & $\begin{array}{l}\text { Measured available soil water }+100 \% \text { of } \\
\text { average growing season precipitation }\end{array}$ & $\begin{array}{l}\text { Wheat, corn, proso millet, foxtail millet, } \\
\text { sunflower, soybean, canola, pea, forage pea, } \\
\text { forage triticale }\end{array}$ \\
\hline OC3 & $\begin{array}{l}\text { Measured available soil water }+70 \% \text { of average } \\
\text { growing season precipitation }\end{array}$ & $\begin{array}{l}\text { Wheat, corn, proso millet, foxtail millet, } \\
\text { sunflower, soybean, canola, pea, forage pea, } \\
\text { forage triticale }\end{array}$ \\
\hline OC4 & $\begin{array}{l}\text { Measured available soil water }+130 \% \text { of } \\
\text { average growing season precipitation }\end{array}$ & $\begin{array}{l}\text { Wheat, corn, proso millet, foxtail millet, } \\
\text { sunflower, soybean, canola, pea, forage pea, } \\
\text { forage triticale }\end{array}$ \\
\hline
\end{tabular}

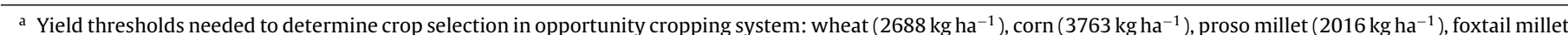
(4256 kg ha $\left.{ }^{-1}\right)$, sunflower (1232 $\left.\mathrm{kg} \mathrm{ha}^{-1}\right)$, soybean (2352 $\left.\mathrm{kg} \mathrm{ha}^{-1}\right)$, canola (1120 $\left.\mathrm{kg} \mathrm{ha}^{-1}\right)$, pea (1568 $\left.\mathrm{kg} \mathrm{ha}^{-1}\right)$, forage pea $\left(4256 \mathrm{~kg} \mathrm{ha}^{-1}\right)$, forage triticale $\left(4256 \mathrm{~kg} \mathrm{ha}^{-1}\right)$. 
Table 4

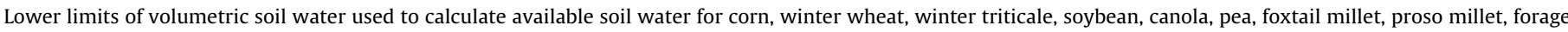
pea, and sunflower on a Weld silt loam, Akron, CO.

\begin{tabular}{|c|c|c|c|c|}
\hline Soil depth (m) & Corn & Winter wheat, winter triticale, soybean, canola & Pea, foxtail millet, proso millet, forage pea & Sunflower \\
\hline $0.0-0.3$ & 0.110 & 0.090 & 0.100 & 0.120 \\
\hline $0.3-0.6$ & 0.135 & 0.120 & 0.129 & 0.126 \\
\hline $0.6-0.9$ & 0.087 & 0.072 & 0.087 & 0.071 \\
\hline $0.9-1.2$ & 0.074 & 0.061 & 0.067 & 0.054 \\
\hline $1.2-1.5$ & 0.079 & 0.082 & 0.086 & 0.049 \\
\hline $1.5-1.8$ & 0.101 & 0.111 & 0.119 & 0.064 \\
\hline
\end{tabular}

of April for corn and soybean decision; end of May for proso millet, foxtail millet, and sunflower decision). Total seasonal water use was calculated from the water balance as the difference between beginning and ending soil water readings plus growing season $\mathrm{pr}$ ecipitation (runoff and deep percolation were assumed to be negligible, considered a reasonable assumption as the slope in the plot area was $<1 \%$ and visual observation in the plot area following heavy rains did not show evidence of runoff).

The yield, water use, WUE, and PUE of these four OC systems were compared against observations from four set rotations: wheat-fallow (conventional till) [WF (CT)], wheat-fallow (no till) $[\mathrm{WF}(\mathrm{NT})]$, wheat-corn-fallow (no till) [WCF (NT)], and wheat-millet (no till) [WM (NT)]. The WUE was calculated as grain yield ( or dry matter yield for forage crops) divided by the total water use. The PUE was calculated as the grain yield (or dry matter yield for forage crops) divided by the total precipitation received over the entire period of the cropping system (2001-2005 for the cropping systems in this experiment).

Due to the different photosynthetic costs of producing oil, protein, and starch, the PUE changes with proportion of crop types in a cropping system. These differences in PUE do not necessarily reflect inherent rotation water wastage or crop physiological inefficiencies. The principle of supply and demand generally takes this into account so that the photosynthetically costly plant products (oil, protein) are worth more than the less costly plant products (starch). Using gross dollars produced per unit of precipitation received, as suggested by Nielsen et al. (2005), can be a more useful way of determining the efficiency with which a given cropping system or rotation makes use of water when comparing across crop types. We calculated the value-basis precipitation use efficiency (\$PUE) as the dollars received for the total grain or dry matter produced
Table 5

Average prices received (1992-2001) for crops.

\begin{tabular}{ll}
\hline Crop & Price $^{\mathrm{a}}\left(\mathrm{US} \mathrm{kg}^{-1}\right)$ \\
\hline Winter wheat & 0.1179 \\
Corn & 0.0941 \\
Sunflower & 0.2147 \\
Pea & 0.0780 \\
Proso millet & 0.1270 \\
Canola & 0.2147 \\
Foxtail millet & 0.0937 \\
Forage pea & 0.0937 \\
\hline
\end{tabular}

a All prices obtained from http://www.nass.usda.gov (verified 1 March 2010).

divided by the total precipitation received over the entire period of the cropping system (2001-2005 for the cropping systems in this experiment). The precipitation amounts are not the same for all cropping systems over this period because the sums are computed from the planting of the first crop to the harvest of the last crop, and those starting and ending dates vary depending on the crops selected to begin and end the cropping system. The 10-year average market values (1992-2001) used were the same as given in Nielsen et al. (2005), shown in Table 5. Net returns were calculated using the expenses shown in Table 6.

Prior to the beginning of the current study the plots were cropped with a somewhat similar decision strategy. The crops planted in the 3 years previous to the beginning of the current study were wheat, wheat, corn (OC1); corn, proso millet, pea (OC2); wheat, corn, sunflower (OC3); and wheat, sunflower, and oats for forage (OC4).

Table 6

Production costs used to calculate expenses in calculating net returns for cropping systems analysis.

\begin{tabular}{|c|c|c|c|c|c|c|}
\hline Operation & Crop/herbicide & Operation cost $\left(\$ \mathrm{ha}^{-1}\right)$ & Seed cost & Herbicide cost $\left(\$\right.$ ha $\left.^{-1}\right)$ & Fertilizer cost $\left(\$ \mathrm{~kg}^{-1}\right)$ & Hauling \\
\hline \multirow[t]{5}{*}{ Planting } & Corn, sunflower & $\$ 24.70$ & $\$ 1.3751000$ seed $^{-1}$ & & & \\
\hline & Wheat & $\$ 22.23$ & $\$ 0.265$ ha & & & \\
\hline & Pea, forage pea & $\$ 22.23$ & $\$ 0.260$ ha & & & \\
\hline & Foxtail, proso millet & $\$ 22.23$ & $\$ 0.260$ ha & & & \\
\hline & Canola & $\$ 22.23$ & $\$ 5.620$ ha & & & \\
\hline \multirow[t]{4}{*}{ Spraying } & Glyphosate & $\$ 12.97$ & & $\$ 12.35$ & & \\
\hline & Paraquat & $\$ 12.97$ & & $\$ 27.00$ & & \\
\hline & Sethoxydim & $\$ 12.97$ & & $\$ 42.56$ & & \\
\hline & $2,4-\mathrm{D}$ & $\$ 12.97$ & & $\$ 2.30$ & & \\
\hline Tillage-sweep plow & & $\$ 14.82$ & & & & \\
\hline Tillage-rod weeder & & $\$ 19.76$ & & & & \\
\hline Tillage-deep chisel & & $\$ 21.00$ & & & & \\
\hline Fertilizing $\mathrm{N}$ & & Applied with planter & & & $\$ 0.82$ & \\
\hline Fertilizing $\mathrm{P}_{2} \mathrm{O}_{5}$ & & Applied with planter & & & $\$ 0.42$ & \\
\hline Swathing small grain & & $\$ 19.76$ & & & & \\
\hline \multirow[t]{3}{*}{ Harvesting and hauling } & Small grains, corn & $\$ 32.11+\$ 3.69 \mathrm{~m}^{-3}$ for $>567 \mathrm{~m}^{3}$ & & & & $\$ 3.69 \mathrm{~m}^{-3}$ \\
\hline & Oilseeds & $\$ 39.52 \mathrm{ha}^{-1}$ & & & & $\$ 5.51 \mathrm{~T}^{-1}$ \\
\hline & Peas & $\$ 44.46 \mathrm{ha}^{-1}$ & & & & $\$ 5.51 \mathrm{~T}^{-1}$ \\
\hline Swathing hay & & $\$ 24.70$ & & & & \\
\hline Baling hay & & $\$ 14.70 \mathrm{~T}^{-1}$ & & & & $\$ 3.23 \mathrm{~T}^{-1}$ \\
\hline
\end{tabular}

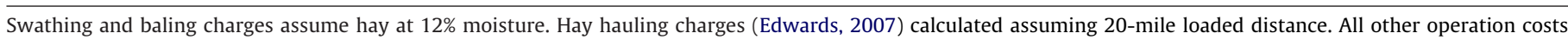
(except hay hauling) come from Tranel et al. (2006). 
Table 7

Measured grain and dry matter yields for four opportunity cropping systems and four set rotations at Akron, $\mathrm{CO}$.

\begin{tabular}{|c|c|c|c|c|c|c|c|c|c|c|}
\hline \multirow[t]{2}{*}{ Year } & \multirow[t]{2}{*}{ OC1 } & \multirow[t]{2}{*}{$\mathrm{OC} 2$} & \multirow[t]{2}{*}{ OC3 } & \multirow[t]{2}{*}{ OC4 } & \multirow[t]{2}{*}{$\mathrm{WF}(\mathrm{CT})$} & \multirow[t]{2}{*}{$\mathrm{WF}(\mathrm{NT})$} & \multicolumn{2}{|l|}{ WCF } & \multicolumn{2}{|l|}{ WM } \\
\hline & & & & & & & & & & \\
\hline \multirow[t]{2}{*}{2001} & Foxtail millet & Wheat & Pea & Canola & Wheat & Wheat & Wheat & Corn & Wheat & Millet \\
\hline & 4545 & 2813 & 1191 & 169 & 3494 & 3926 & 3661 & 4527 & 2472 & 2415 \\
\hline \multirow[t]{2}{*}{2002} & Wheat & Sunflower & Foxtail Millet & Proso Millet & Wheat & Wheat & Wheat & Corn & Wheat & Millet \\
\hline & 1034 & 0 & 0 & 0 & 1628 & 2062 & 2005 & 0 & 594 & 0 \\
\hline \multirow[t]{2}{*}{2003} & Corn & Corn & Fallow & Sunflower & Wheat & Wheat & Wheat & Corn & Wheat & Millet \\
\hline & 2915 & 3138 & 0 & 352 & 3872 & 4406 & 4789 & 3073 & 4365 & 2563 \\
\hline \multirow[t]{2}{*}{2004} & Fallow & Forage Pea & Forage Pea & Proso Millet & Wheat & Wheat & Wheat & Corn & Wheat & Millet \\
\hline & 0 & 3862 & 3502 & 390 & 896 & 2116 & 1807 & 3096 & 310 & 2647 \\
\hline \multirow[t]{2}{*}{2005} & Wheat & Foxtail Millet & Foxtail Millet & Pea & Wheat & Wheat & Wheat & Corn & Wheat & Millet \\
\hline & 2302 & 4717 & 2611 & 564 & 2163 & 2819 & 2256 & 2278 & 599 & 562 \\
\hline
\end{tabular}

OC1-OC4 refer to opportunity cropping systems 1 through 4 as designated in Table 1.

$\mathrm{WF}(\mathrm{CT})$ is wheat-fallow, conventional tillage; WF (NT) is wheat-fallow, no-till; WCF (NT) is wheat-corn-fallow, no-till; WM (NT) is wheat-proso millet, no-till.
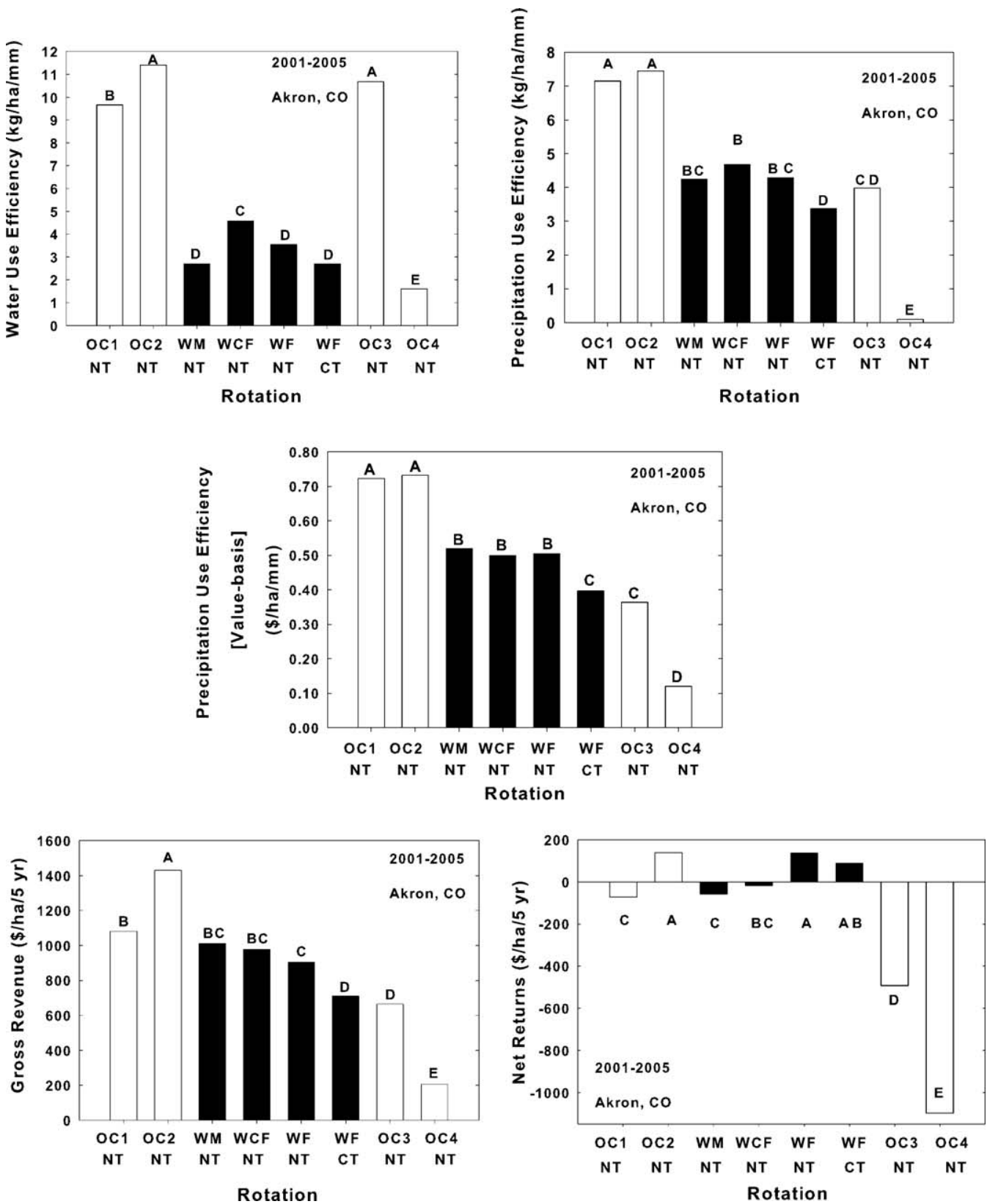

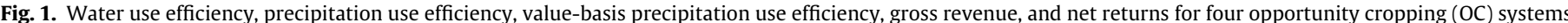
(defined in Table 2) and four set rotations at Akron, $\mathrm{CO}$. W = winter wheat, $\mathrm{M}=$ proso millet, $\mathrm{C}=$ corn, $\mathrm{F}=\mathrm{fallow}, \mathrm{NT}=\mathrm{no}$ till, $\mathrm{CT}=\mathrm{conventional}$ till. 


\section{Results}

\subsection{Sequences and yields}

The 5-year cropping sequence (and measured yields) generated by following the decision rules for OC1 (Table 7) were foxtail millet (dry matter yield of $4545 \mathrm{~kg} \mathrm{ha}^{-1}$ ), wheat (1034 $\mathrm{kg} \mathrm{ha}^{-1}$ ), corn $\left(2915 \mathrm{~kg} \mathrm{ha}^{-1}\right)$, fallow, and wheat $\left(2302 \mathrm{~kg} \mathrm{ha}^{-1}\right)$. Following the decision rules for OC2 (which assumed average growing season precipitation) resulted in a cropping sequence (and measured yields) of wheat $\left(2813 \mathrm{~kg} \mathrm{ha}^{-1}\right)$, sunflower $\left(0 \mathrm{~kg} \mathrm{ha}^{-1}\right.$ due to severe drought), corn ( $\left.3138 \mathrm{~kg} \mathrm{ha}^{-1}\right)$, forage pea (dry matter yield of $3862 \mathrm{~kg} \mathrm{ha}^{-1}$ ), and foxtail millet (dry matter yield of $4717 \mathrm{~kg} \mathrm{ha}^{-1}$ ). The OC3 decision rules (which assumed $70 \%$ of average growing season precipitation) called for growing four crops in 5 years in a sequence of pea $\left(1191 \mathrm{~kg} \mathrm{ha}^{-1}\right)$, foxtail millet (dry matter yield of $0 \mathrm{~kg} \mathrm{ha}^{-1}$ due to severe drought), fallow, forage pea (dry matter yield of $3502 \mathrm{~kg} \mathrm{ha}^{-1}$ ), and foxtail millet (dry matter yield of $2611 \mathrm{~kg} \mathrm{ha}^{-1}$ ). The OC4 decision rules called for the most intensive cropping due to the assumption of $130 \%$ of normal growing season precipitation. This method resulted in a cropping sequence which produced very low yields: canola $\left(169 \mathrm{~kg} \mathrm{ha}^{-1}\right)$, proso millet ( $0 \mathrm{~kg} \mathrm{ha}^{-1}$ due to severe drought), sunflower $\left(352 \mathrm{~kg} \mathrm{ha}^{-1}\right)$, proso millet $\left(390 \mathrm{~kg} \mathrm{ha}^{-1}\right)$, and pea $\left(563 \mathrm{~kg} \mathrm{ha}^{-1}\right)$. The average wheat yields for the four set rotations were $2411 \mathrm{~kg} \mathrm{ha}^{-1}$ (WF (CT)), $3066 \mathrm{~kg} \mathrm{ha}^{-1}$ (WF(NT)), $2904 \mathrm{~kg} \mathrm{ha}^{-1}$ (WCF(NT)), and $1668 \mathrm{~kg} \mathrm{ha}^{-1}$ (WM (NT)). Average corn yield in the WCF (NT)) system was $2595 \mathrm{~kg} \mathrm{ha}^{-1}$ and average proso millet yield in the WM(NT)) system was $1637 \mathrm{~kg} \mathrm{ha}^{-1}$.

\subsection{Water use efficiency and precipitation use efficiency}

Water use efficiency (Fig. 1, top left panel) was greatest following the $\mathrm{OC} 2$ and $\mathrm{OC} 3$ decision rules (both systems having two forage crops in 5 years) followed by the OC1 strategy (one forage crop in 5 years) with values between 9.66 and $11.40 \mathrm{~kg} \mathrm{ha}^{-1} \mathrm{~mm}^{-1}$. The OC4 decision rule resulted in the lowest WUE of $1.61 \mathrm{~kg} \mathrm{ha}^{-1} \mathrm{~mm}^{-1}$ because of the very low seed yields obtained in all 5 years. The WUE for the WCF system $\left(4.59 \mathrm{~kg} \mathrm{ha}^{-1} \mathrm{~mm}^{-1}\right)$ was the greatest of the set rotations, but less than half of that obtained by OC1, OC2, and OC3, because of the system producing only seed and no forage.

Precipitation use efficiency (Fig. 1, top right panel) was greatest for the OC1 and OC2 systems (about $7.29 \mathrm{~kg} \mathrm{ha}^{-1} \mathrm{~mm}^{-1}$ ). The PUE of the OC3 system was much lower $\left(3.98 \mathrm{~kg} \mathrm{ha}^{-1} \mathrm{~mm}^{-1}\right)$ because of 2 years without crop production (crop failure due to drought in 2002 and a fallow year in 2003, Table 7). The PUE of the OC4 system was extremely low $\left(0.1 \mathrm{~kg} \mathrm{ha}^{-1} \mathrm{~mm}^{-1}\right)$, while PUE for the set rotations ranged between $3.37 \mathrm{~kg} \mathrm{ha}^{-1} \mathrm{~mm}^{-1}$ (WF (CT)) and $4.69 \mathrm{~kg} \mathrm{ha}^{-1} \mathrm{~mm}^{-1}$ (WCF).

The value-basis PUE (Fig. 1, center panel) allows a fairer comparison of cropping systems that have mixes of forages, seed legumes, and grains. The \$PUE was greatest for OC1 and OC2 $\left(\$ 0.73 \mathrm{ha}^{-1} \mathrm{~mm}^{-1}\right)$ with \$PUE for OC3 being similar to WF (CT) $\left(\$ 0.38 \mathrm{ha}^{-1} \mathrm{~mm}^{-1}\right)$. The \$PUE for the other three set rotations was intermediate $\left(\$ 0.51 \mathrm{ha}^{-1} \mathrm{~mm}^{-1}\right.$ ) while the lowest \$PUE was generated by following the OC4 decision rules $\left(\$ 0.12 \mathrm{ha}^{-1} \mathrm{~mm}^{-1}\right)$. The lower PUE and \$PUE for OC3 compared with OC1 and OC2 is primarily attributable to the very dry conditions in 2002 which resulted in no foxtail millet yield, followed by a decision rule result to fallow in 2003 due to low soil water content and an assumed growing season precipitation of $70 \%$ of average. Had there been sufficient soil water in the fall of 2002 to predict a wheat yield that met or exceeded the wheat yield decision threshold $\left(2688 \mathrm{~kg} \mathrm{ha}^{-1}\right)$, a wheat yield of approximately $4200 \mathrm{~kg} \mathrm{ha}^{-1}$ likely would have been achieved (see wheat yields for 2003 in the set rotations, Table 7) resulting a system \$PUE of $\$ 0.63 \mathrm{ha}^{-1} \mathrm{~mm}^{-1}$ (lower than OC1 and OC2, but higher than the set rotations), nearly double what was actually obtained.

\subsection{Gross revenues and net returns}

The gross revenues (Fig. 1, lower left panel) were greatest when the OC2 decision rules were followed ( $\left.\$ 1431 \mathrm{ha}^{-1} 5 \mathrm{yr}^{-1}\right)$. Following the OC1 decision rules produced gross revenues similar to those generated by the WM and WCF cropping systems ( $\$ 978-1081 \mathrm{ha}^{-1}$ $\left.5 \mathrm{yr}^{-1}\right)$. The OC3 strategy produced gross revenues similar to WF (CT) (about $\$ 689 \mathrm{ha}^{-1} 5 \mathrm{yr}^{-1}$ ). As with the production efficiency measures discussed above, gross revenues were least when the OC4 decision rules were followed ( $\$ 205 \mathrm{ha}^{-1} 5 \mathrm{yr}^{-1}$ ) because of the very low yields obtained.

The very low yields with OC4 resulted in the most extreme economic losses ( $\left.-\$ 1097 \mathrm{ha}^{-1} 5 \mathrm{yr}^{-1}\right)$ among the systems being compared (Fig. 1, lower right panel). The OC3 system also exhibited large economic losses $\left(-\$ 493 \mathrm{ha}^{-1} 5 \mathrm{yr}^{-1}\right.$ ) because of the 2 years without any crop production. Net returns were negative as well for OC1, WM, and WCF, but to a much lesser degree. Positive net returns were seen for WF (CT) $\left(\$ 89 \mathrm{ha}^{-1} 5 \mathrm{yr}^{-1}\right), \mathrm{WF}(\mathrm{NT})$ $\left(\$ 138 \mathrm{ha}^{-1} 5 \mathrm{yr}^{-1}\right)$, and OC2 (\$136 ha-1 $\left.5 \mathrm{yr}^{-1}\right)$.

\section{Discussion}

As pointed out earlier in the case of the low \$PUE value for OC3 resulting from no crop planted in 2003, there may be missed opportunities to plant and harvest a crop because of the inability to forecast long-range precipitation. While Steiner et al. (2004) expressed optimism in improved long-range seasonal forecasts in semi-arid regions that might aid farmers in making cropping choice decisions, it is our opinion that improvement in long-range forecasting of growing season precipitation in the central Great Plains, which largely occurs as a result of convective thunderstorm activity that is highly variable in time and space, is not likely to occur. Lyon et al. (2003) also concluded that long-range forecasts of summer precipitation in western Nebraska using the Southern Oscillation Index (Stone and Auliciems, 1992) lacked sufficient skill to be useful in making cropping decisions regarding corn.

The OC1 and OC2 decision rule strategies appear to be more efficient users of water and precipitation than the set rotations, but were not statistically different from the WF (CT) and WF (NT) set rotations in net returns generated. It should be kept in mind, though, that $\mathrm{OC} 1, \mathrm{OC} 2$, and OC3 all had forages in some years and the cost of hauling can be a large factor in increasing or decreasing profitability compared with the set rotations depending on transportation costs (we used a forage hauling cost of $\$ 3.23$ per ton based on a 20 -mile hauling distance).

Additionally, conclusions regarding the profitability differences between systems should be drawn cautiously. From the economic analysis given in this study, a farmer would have been no further ahead using the OC1 strategy than using set rotations of WM or WCF, or using the OC2 strategy instead of set rotations of WF (CT) or WF (NT). Perhaps this conclusion would change in favor of the OC systems if more years of data were available for analysis, as one of the 5 years used in this study was from the most severe drought on record for this location. As evidence that the years selected and the number of years of record can affect the conclusions drawn, we cite another northeastern Colorado cropping systems study (Kaan et al., 2002; Peterson and Westfall, 2004) that used data from 1989 to 1997 (a relatively wetter set of years, in terms of both annual and growing season precipitation compared with the 2001-2005 period used in this study). They concluded that net returns from the WCF system were $25-40 \%$ greater than from $W F(N T)$, very different than the much greater net returns for WF (NT) compared with WCF 


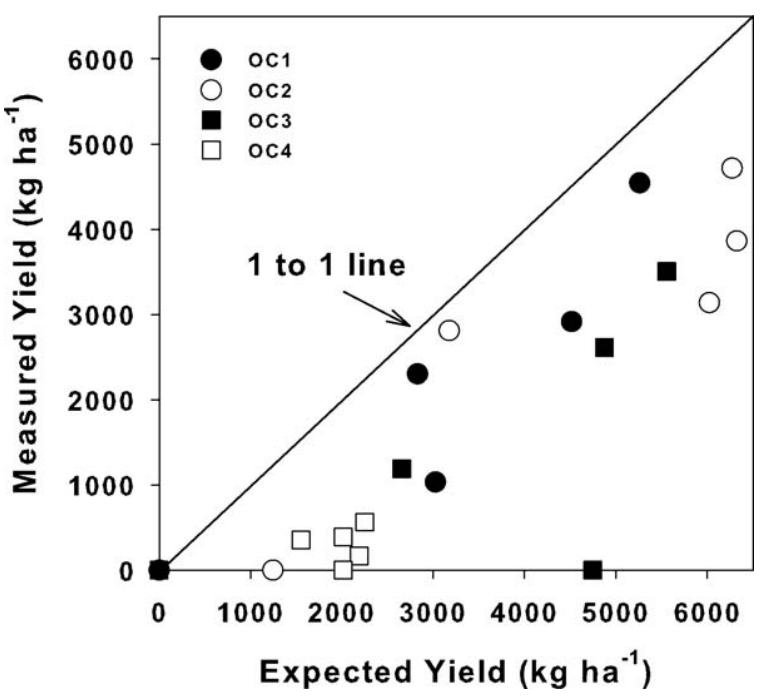

Fig. 2. Comparison of expected crop yield (generated prior to growing season from water use/yield production functions) and measured yields for four opportunity cropping (OC) systems (defined in Table 2).

found in the current study. Lyon et al. (2003) also cautioned that different conclusions regarding profitable dryland corn populations for western Nebraska could be drawn depending on whether studies were conducted during the relatively wetter 1990s period vs. the drier early 2000s.

The OC4 decision rules could be considered a non-viable crop selection strategy as evaluated by any one of the measures shown in Fig. 1. The assumption of $130 \%$ of average growing season precipitation was not met even once in the 5 years of the study. The year that came closest to meeting that assumption was 2004 when the millet growing season precipitation was $116 \%$ of average. Clearly, basing a cropping decision on a continuing optimistic prediction of above-average growing season rainfall is not wise in this semiarid climate where annual precipitation records indicate rainfall amounts fluctuating widely about the mean on a nearly annual basis (Nielsen and Vigil, 2009). On the other hand, the OC2 strategy that based crop choice on available soil water at planting and a prediction of average growing season rainfall resulted in continuous cropping (although no crop was produced in 2002 because of severe drought) producing a cropping sequence that was highly efficient in terms of water and precipitation use, more profitable than WM and WCF, and equal in profitability to WF (CT) and WF (NT).

Surprisingly, none of the four OC systems resulted in measured yields greater than the expected yields generated by the production functions combined with the measured available soil water and expected precipitation (Fig. 2). In fact, most of the measured yields were far below the expected yields. In only three instances (two for OC1 and one for OC2) did measured yield fall within $20 \%$ of expected yield. This result of always obtaining measured yields lower than expected yields was not expected because measured growing season precipitation was above expected growing season precipitation in 3 years for OC1, 2 years for OC2, and 4 years for OC3. This lack of ever achieving a measured yield greater than expected may indicate that (1) the production functions need to be refined or (2) water stress during critical stages of development are more detrimental to yield than can be accounted for by this simple yield prediction system or (3) all of the available soil water measured at the decision points is not really ultimately available to the crop during the growing season and different lower limits of water availability will need to be established. Two recent analyses of dryland corn yield sensitivity to water deficits during pollination and grain filling explain why the measured corn yields may be lower than expected (Nielsen et al., 2009, 2010).

\section{Conclusions}

Using estimated crop water use (measured available soil water at several decision points during the year plus $70-100 \%$ of average growing season precipitation) with established water use/yield production functions can assist farmers in making a crop choice that can increase cropping frequency, WUE, PUE, and \$PUE over that obtained with set rotations. The crop prices and production costs used in the economic analysis of this study did not reveal a net revenue advantage for an OC system over a set WF rotation, but did indicate an advantage over the WM and WCF rotations. Even though none of the OC crop selection methods resulted in a net revenue advantage of the WF systems, producers may want to consider using the OC2 method to increase cropping frequency over the WF systems because of the potential benefits associated with increasing surface soil organic carbon and particulate organic matter levels (Mikha et al., 2010), greater carbon sequestration (Halvorson et al., 2002), reducing exposure to wind erosion (McMaster et al., 2000), reducing surface soil compaction (Blanco-Canqui et al., 2010), and improvement to other physical properties of the soil (Benjamin et al., 2007). An OC decision support system would benefit from combining the method described in this paper with economic factors (estimated costs and revenues) for the various crops for which pre-season yield estimates are made.

\section{References}

Anderson, R.L., 1998. Designing rotations for a semiarid region. In: Proc. 10th Annua Colorado Conserv. Tillage Assoc. Meeting, Sterling, CO, 3-4 February, pp. 4-15. Anderson, R.L., Bowman, R.A., Nielsen, D.C., Vigil, M.F., Aiken, R.M., Benjamin, J.G., 1999. Alternative crop rotations for the central Great Plains. J. Prod. Agric. 12 95-99.

Benjamin, J.G., Mikha, M., Nielsen, D.C., Vigil, M.F., Calderón, F., Henry, W.B., 2007. Cropping intensity effects on physical properties of a no-till silt loam. Soil Sci. Soc. Am. J. 71, 1160-1165.

Blanco-Canqui, H., Stone, L.R., Schlegel, A.J., Benjamin, J.G., Vigil, M.F., Stahlman, P.W., 2010. Continuous cropping systems reduce near-surface maximum compaction in no-till soils. Agron. J. 102, 1217-1225.

Bowman, R.A., Halvorson, A.D., 1997. Crop rotation and tillage effects on phosphorus distribution in the central Great Plains. Soil Sci. Soc. Am. J. 61, 1418-1422.

Brown, P.L., Carlson, G.R., 1990. Grain Yields Related to Stored Soil Water and Growing Season Rainfall. Agric. Exp. Stn. Spec. Rep. 35. Montana State Univ., Bozeman.

Brown, P.L., Black, A.L., Smith, C.M., Enz, J.W. Caprio, J.M., 1981. Soil Water Guidelines and Precipitation Probabilities for Barley and Spring Wheat in Flexible Cropping Systems in Montana and North Dakota, Montana Coop. Ext. Bull. 356. Montana State Univ., Bozeman.

Dhuyvetter, K.C., Thompson, C.R., Norwood, C.A., Halvorson, A.D., 1996. Economics of dryland cropping systems in the Great Plains: a review. J. Prod. Agric. 9, 216-222.

Edwards, W., 2007. 2007 Iowa Farm Custom Rate Survey. Ag Decision Maker File A3-10. Iowa State University, Ames, Available at http://www.extension.iastate.edu/NR/rdonlyres/FD84BED8-516D-4FAA9DD2-4F12F8ABECB8/51766/2007CustomRate.pdf (verified 8/25/2010).

Farahani, H.J., Peterson, G.A., Westfall, D.G., 1998. Dryland cropping intensification: a fundamental solution to efficient use of precipitation. Adv. Agron. 64, 225-265.

Felter, D.G., Lyon, D.J., Nielsen, D.C., 2006. Evaluating crops for a flexible summer fallow cropping system. Agron. J. 98, 1510-1517.

Halvorson, A.D., Reule, C.A., 1994. Nitrogen fertilizer requirements in an annual dryland cropping system. Agron. J. 86, 315-318.

Halvorson, A.D., Wienhold, B.J., Black, A.L., 2002. Tillage, nitrogen, and cropping system effects on soil carbon sequestration. Soil Sci. Soc. Am. J. 66, 906-912.

Hinze, G.O., Smika, D.E., 1983. Cropping practices: Central Great Plains. In: Dregne, H.E., Willis, W.O. (Eds.), Dryland Agriculture. Agron. Monogr. 23. ASA, CSSA, and SSSA, Madison, WI, pp. 387-395.

Kaan, D.A. O'Brien, D.M., Burgerner, P.A., Peterson, G.A., Westfall, D.G, 2002. An Economic Evaluation of Alternative Crop Rotations Compared to Wheat-fallow in Northeastern Colorado. Technical Bulletin TB02-1. Agricultural Experiment Station, Fort Collins, CO.

Lyon, D.J., Boa, F., Arkebauer, T.J., 1995. Water-yield relations of several springplanted dryland corps following winter wheat. J. Prod. Agric. 8, 281-286.

Lyon, D.J., Hammer, G.L., McLean, G.B., Blumenthal, J.M., 2003. Simulation supplements field studies to determine no-till dryland corn population recommendations for semiarid western Nebraska. Agron. J. 95, 884-891.

Lyon, D.J., Nielsen, D.C., Felter, D.G., Burgener, P.A., 2007. Choice of summer fallow replacement crop impacts subsequent winter wheat. Agron. J. 99, 578-584. 
McMaster, G.S., Aiken, R.M., Nielsen, D.C., 2000. Optimizing wheat cutting height for harvest efficiency and soil and water conservation. Agron. J. 92, 11041108.

Mikha, M.M., Benjamin, J.G., Vigil, M.F., Nielsen, D.C., 2010. Cropping intensity impacts on soil aggregation and carbon sequestration in the central Great Plains. Soil Sci. Soc. Am. J. 74, 1712-1719.

Musick, J.T., Jones, O.R., Stewart, B.A., Dusek, D.A., 1994. Water-yield relationships for irrigated and dryland wheat in the U.S. southern plains. Agron. J. 86, 980-986.

Nielsen, D.C., 1990. Scheduling irrigations for soybeans with the Crop Water Stress Index (CWSI). Field Crops Res. 23, 103-116.

Nielsen, D.C., 1995. Water Use/Yield Relationships for Central Great Plains crops. Conservation Tillage Fact Sheet \#2-95. Central Great Plains Res. Stn, Akron, CO.

Nielsen, D.C., 1998. Comparison of three alternative oilseed crops for the central Great Plains. J. Prod. Agric. 11, 336-341.

Nielsen, D.C., 1999. Water requirements and potential impacts on following crops. In: Meyer, R., Belshe, D., O'Brien, D. (Eds.), High Plains Sunflower Production Handbook, MF-2384. Kansas State University, Manhattan, pp. 8-11.

Nielsen, D.C., 2001. Production functions for chickpea, field pea, and lentil in the central Great Plains. Agron. J. 93, 563-569.

Nielsen, D.C., 2006a. Central Great Plains Yield Calculator, CD Version 2.2. CD-ROM. Central Great Plains Research Station, Akron, CO, Available at http://www.ars.usda.gov/services/docs.htm?docid=19206, verified 4/1/2010.

Nielsen, D.C., 2006b. Crop water use and yield. In: Proc. Wheat-based Cropping Systems Workshop, Colo. State Univ. Coop. Ext., Sterling, CO, December 14.

Nielsen, D.C., Vigil, M.F., 2009. Precipitation storage efficiency during wheat fallow in wheat-fallow systems. Agron. J. 102, 537-543.

Nielsen, D.C., Anderson, R.L., Bowman, R.A., Aiken, R.M., Vigil, M.F., Benjamin, J.G., 1999. Winter wheat and proso millet yield reduction due to sunflower in rotation. J. Prod. Agric. 12, 193-197.

Nielsen, D.C., Vigil, M.F., Anderson, R.L., Bowman, R.A., Benjamin, J.G., Halvorson, A.D., 2002. Cropping system influence on planting water content and yield of winter wheat. Agron. J. 94, 962-967.

Nielsen, D.C., Unger, P.W., Miller, P.R., 2005. Efficient water use in dryland cropping systems in the Great Plains. Agron. J. 97, 364-372.

Nielsen, D.C., Vigil, M.F., Benjamin, J.G., 2006. Forage yield response to water use for dryland corn, millet, and triticale in the central Great Plains. Agron. J. 98, 992-998.

Nielsen, D.C., Vigil, M.F., Benjamin, J.G., 2009. The variable response of dryland corn yield to soil water content at planting. Agric. Water Manage. 96, 330336.

Nielsen, D.C., Halvorson, A.D., Vigil, M.F., 2010. Critical precipitation period for dryland maize production. Field Crops Res. 118, 259-263.
Norwood, C.A., Schlegel, A.J., Morishita, D.W., Gwin, R.E., 1990. Cropping system and tillage effects on available soil water and yield of grain sorghum and winter wheat. J. Prod. Agric. 3, 356-362.

Peterson, G.A., Westfall, D.G., 2004. Managing precipitation use in sustainable dryland agroecosystems. Ann. Appl. Biol. 144, 127-138.

Peterson, G.A., Westfall, D.G., Cole, C.V., 1993. Agroecosystem approach to soil and crop management research. Soil Sci. Soc. Am. J. 57, 1354-1360.

Pierce, F.J., Rice, C.W., 1988. Crop rotation and its impact on efficiency of water and nitrogen use. In: Cropping Strategies for Efficient Use of Water and Nitrogen. ASA Spec. Publ. 51. ASA, CSSA, and SSSA, Madison, WI, pp. 21-42.

Porter, P.M., Lauer, J.G., Lueschen, W.E., Ford, J.H., Hoverstad, T.R., Oplinger, E.S., Crookston, R.K., 1997. Environment affects the corn and soybean rotation effect. Agron. J. 89, 441-448.

Ratliff, L.F., Ritchie, J.T., Cassel, D.K., 1983. A survey of field-measured limits of soil water availability and related laboratory-measured properties. Soil Sci. Soc. Am. J. 47, 770-775.

Ritchie, J.T., 1981. Soil water availability. Plant Soil 58, 327-338.

Silburn, D.M., Freebairn, D.M., Rattray, D.J., 2007. Tillage and environment in subtropical Australia-tradeoffs and challenges. Soil Till. Res. 97, 306-317.

Smika, D.E., 1990. Fallow management practices for wheat production in the central Geat Plains. Agron. J. 82, 319-323.

Steiner, J.L., Schneider, J.M., Garbrecht, J.D., Zhang, X.J., 2004. Climate forecasts: emerging potential to reduce dryland farmers' risks. In: Challenges and Strategies of Dryland Agriculture, CSSA Spec. Publ. 32. ASA, CSSA, and SSSA, Madison, WI, pp. 47-65.

Stone, R.C., Auliciems, A., 1992. SOI phase relationships in eastern Australia. Int. J. Climatol. 12, 625-636.

Stone, L.R., Schlegel, A.J., 2006. Yield-water supply relationships of grain sorghum and winter wheat. Agron. J. 98, 1359-1366.

Tranel, J.E., Sharp, R.L., Kaan, D.A., Deering, J., 2006. Custom Rates for Colorado Farms and Ranches in 2006. Agirc. Business Manage. Notes section 4 No. 4.5 Colorado State University, Fort Collins, Available at http://www.coopext.colostate.edu/ abm/abmcustrate06.pdf (verified 4/18/2008).

Unger, P.W., 1978. Straw-mulch rate effect on soil water storage and sorghum yield Soil Sci. Soc. Am. J. 42, 486-491.

Unger, P.W., 2001. Alternative and opportunity dryland crops and related soil conditions in the southern Great Plains. Agron. J. 93, 216-226.

Weisensel, W.P., Van Kooten, G.C., Schoney, R.A., 1991. Relative riskiness of fixed vs. flexible crop rotations in the dryland cropping region of western Canada. Agribusiness 7, 551-562.

Young, D.L., van Kooten, G.C., 1989. Economics of flexible spring cropping in a summer fallow region. J. Prod. Agric. 2, 173-178. 